\begin{tabular}{|c|c|c|c|}
\hline$\Perp^{n}$ & Received 10/03/2019 & $\sqrt{\overline{E E}}$ & Published 28/04/2019 \\
\hline
\end{tabular}

\title{
Reconstruction of Islamic Education Curriculum in The Disruption Era
}

\author{
${ }^{1}$ Desfa Yusmaliana, ${ }^{2}$ Hendro Widodo \\ Email : yusmaliana.desfa@yahoo.co.id ${ }^{1}$, hwmpaiuad@gmail.com ${ }^{1}$
}

${ }^{1}$ Universitas Ahmad Dahlan, Yogyakarta, Indonesia

ABSTRACT
This study aims to reconstruct the curriculum of Islamic education in Keywords
facing the disruption era. So far, the Islamic education curriculum has not Islamic education
been prepared to face the disruption era which is full of changes. The curriculum;
formal Islamic education curriculum is too crowded with rigid learning Reconstruction;
administration activities, not inspiration and enlightenment that can build Disruption era
awareness, especially character. This research is a literature review with
a qualitative descriptive approach. The results showed that the
reconstruction of the Islamic education curriculum in the disruption era is
an Islamic education curriculum that developed the character of the
millennial generation with digital technology-based learning tools so that
learning became more inspiring, enlightening, and building up the Islamic
values

\section{INTRODUCTION}

The education trilogy, which was initiated by Ki Hadjar Dewantara (Rusydi, 2014) (Rusydi, 2014) said that the mechanism of education is portrayed by the family, school and the community. The concept of education is developed through a system called education curriculum. Education will not work if no one controls it; the curriculum is like a heart in a human being (Asri, 2017).

In the revolutionary era 4.0, the implementation of the 2013 curriculum has brought a more revolutionary theme, which is to produce creative, innovative, and essential humanity through integrated attitudes, skills, and knowledge (Mulyasa, 2015) in developing the generation mentality. The integration of the various results expected from an educational give a major challenge, especially in Islamic Education, which does not only play a role in developing students' potential cognitively but also on forming the character and the religious spirit (Purwati, 2016). For this reason, changes in the Islamic education curriculum should be carried out. Not only in Indonesia, but several Muslim countries have responded to changes in traditional education towards modernization as well (Talbani, 2018). As one reason for the change, for example is the subjects of hadith, fiqh, kalam, and interpretations that are central of the Islamic material and part of curriculum are no longer able to provide complete answers to Islam if only taught through books (Khotimah, 2014). Therefore, the integration of various methods and approaches in the learning process needs to be carried out. For example, STAIN Ponorogo lecturer has 
integrated active learning and internet-based learning into the teaching program to the students of the Islamic primary school education Study Program. As a result, it can improve student learning activeness and creativity (Effendi, 2013). It showed that the disruption era, which characterized by globalization in the living process, the advancement of science and technology, the rapid transformation of technology, and communication has led to a series of substantial changes in the world order (Oviyanti, 2013) including the education.

By looking at the importance of the Islamic Education process in shaping humans to be capable of developing themselves and the society, the environment and the state (Anwar, 2016), the Islamic education curriculum will continue to experience renewal and reconstruction to be better as the Minister of Education and Culture revealed that the change and development of the 2013 Curriculum is something that must be done immediately because of its importance and crucial (Mulyasa, 2015).

\section{DISCUSSION \\ Islamic Education Process}

The definition of education and teaching is varied depending on the point of view. Socrates and Plato (Wenger, 2003) believed that all knowledge already exists in every individual; it only needs to be drawn out with certain stimulations. For this reason, the origin of "education" is "educate" means "pulling out of." However, the meaning of this education concept seems to deviate from what it should be. Education only focuses on giving lesson material until the last page of a book. Though student, in this case, is the subject of education who has a tremendous potential to develop. Agreeing with this, Buzan [10. p. 137] told that in term of the new knowledge, the previous emphasis which taught students about the facts related to the subjects in the school curriculum, first of all the students should be informed about themselves; about how they can think, learn, remember, solve problems, be creative, and so forth. In other words, education is not only measuring what a child can do but rather a process of guiding what they can do (Cooper, 2004).

Thus, the educational process will use and maximize the potential that exists through various stimulation so it can augment creativity as the highest part of the learning concept. As the level of thinking from bloom taxonomy concept which revised by a group of educators in 2001 there are some levels: at the lowest level, the knowledge level has been changed to be remembering level, which can also occur at some other levels as well. The comprehension level has been replaced by understanding where the term is most often used by educators when delivering lessons. Similarly, application, analysis, evaluation are replaced by applying, analyzing and evaluating. Furthermore, the synthesis is exchanged for its position with an assessment that changes to be created as the highest level of the thinking process (Sousa, 2012).

Deeper, education is not merely a process of internalizing the knowledge, but also a tool of the acculturation, a socialization of the civilization and distribution of the life values (El-Rahman, 2017). In Islamic education, according to Jalaluddin [19 p. 251], although some experts have not found yet the agreement about the originality of the human diversity spirit, it is generally recognized that education has 
an important role in developing values and religious attitudes started from family, school, and society. In the context of Islam, Allah has taught us in the Qur'an (Luqman verses 12-19) about the core of an Islamic education curriculum is teachings of aqeedah, sharia and muamalah. Therefore, the purpose of education, both general and specific goals must be clear. Hasan Langgulung (Mumtahanah, 2011) formulated that the objectives of that are to form a faithful person (metaphysical/transcendental) and a pious person (physical/profane).

The importance of the Islamic education goal indeed occupies the education process as a central between input and output. Fazlur Rahman (Khotimah, 2014) revealed that the process means a series of changes in developing something which includes acting, making, or processing to produce a product or in other words to gain the knowledge. Not only that, the internalization of religious moral values in the learning process is also an important part that must be developed. Thus, the experience received is more meaningful (Murdiono, 2010) and Islamic education becomes one of the main pillars in character education (Ainiyah, 2013). The PAI curriculum determines the type and quality of education that makes graduates have a globlal insight (Zalik Nuryana, 2017)

\section{Islamic Education Curriculum Reconstruction}

Since the use of a word currere for the first time as a curriculum, which means the distance in a race by the ancient Romans, it has been seen that the meaning of the curriculum is comprehensive, starting from the start to the finish line. The purpose of education is a reference to education achievement and successfulness. Therefore, the education curriculum will be full of contents that support the performance of these objectives, such as subject matter, teaching methods, assessment methods (Mumtahanah, 2011) and so on. In Arabic, the word 'manhaj' is often used as a curriculum word, which means a bright path (Langgulung, 1986). By looking at the meaning of the curriculum, this has illustrated the message more to Islamic education. Not only the way to go, but it also requires enlightenment on a journey.

So far, the formal Islamic education curriculum has been heavily packed with a series of administrations that must be fulfilled, so in the end, disregarding the function of the curriculum. Even though, based on the curriculum function, it has a role as a study program, content, planning activities, learning outcomes, cultural reproduction, learning experience, and production (Bahri, 2011). The function will undoubtedly grow as the development of an era which more sophisticated from time to time.

It cannot be denied that globalization has a significant influence on the character, values, and mentality of a nation (Sauri, 2010). During the development era, Islamic education is considered responsible for this (Azra, 2001). Even though this simplicity views cannot be fully justified, Islamic education should be built and reconstructed soon. Western penetration to the Islamic world since the 18th century has opened the eyes and realized the decline of the Islamic world (Fazlurrahman, 2018) and for this reason, Islamic education needs to make renewal on the curriculum 
A fundamental thing in reconstruction is the critical analysis of theories and activities which have been and are being carried out. Manab [p. 146] took the concept of currere by Pinar (1976) that construction is described in four stages of biographical reflection: regressive, progressive, analytical and synthetic. In the backward step or back to the past, or the writer says as a process of introspection, educational experience is of particular concern, especially in schooling, material, educators, and other pedagogy artifacts in order to proceed in the next direction which is progressive or step forward by imagining that there are no and possibilities that will occur in the future. The next step is analytic, which means confining or analyzing what has happened, which is now being and even on what will happen in the future, after this analytical process will be a clarification of the misuse of the philosophy contained in experience and education itself in forms of curriculum theory that should be clearer, smoother, and conceptualized towards more complete goals over time. The proper form of curriculum reconstruction will make great cadres who have concern for the association. A good cadre will increase progressive civil society in the world (Nuryana, Rahman, \& Setiawan, 2019)

Munzir Hitami revealed that there are at least three principles of curriculum design (Ma'arif, 2017). First, a religious approach that is developed towards the science branches. Second, freeing the religious content or subject matter from meaningless. Third, planning each component fully consideration or Syed Ali Ashraf and Syed Sajjad Husein called it the principle of continuity, sequencing, and integration (Umam, 2018). Moreover, Islamic education is not only centered on cognitive aspects but also affective and psychomotor, so the position of the curriculum becomes critical. This is because the process of developing these values can only occur through a meaningful learning process. Soedijarto revealed that the learning process could only be effective and efficient if done through a curriculum system that has been designed in such a way, started by setting the goals to be achieved, the content of lessons to be learned, the processes to be implemented and the assessment systems that will be developed [35. p. 91]. Therefore, curriculum changes will be temporal, conceptual and innovative.

The central position of the curriculum in the education process is visible from the realization of educational goals. According to Mauritz Johnson, the curriculum determines (or at least anticipates) the results of instruction. Furthermore, in the education process, the curriculum is also a plan, guidance, and guideline about the material, type, scope, and sequence to be carried out (Ahid, 2006). Therefore, in this situation the curriculum will continue to experience changes to achieve educational goals in a better direction from time to time. It has happened in Indonesia in 1947, 1968, 1975, 1984, 1994, CBSA, KBK, and KTSP (Wirianto, 2014) and currently known as the 2013 curriculum.

Like a vehicle that carries the passengers to the destination place, the curriculum is the same. For this reason, in a school, the curriculum is the core of the school, which is often offered to the public and becomes one of a standard point in choosing the best school. For example, there are parents who prefer their children educated in private schools compared to public schools due to the student's quantity in one class. It based on the idea that with fewer students in private schools, their children would receive more 
attention from their teachers (Rose \& Nichall, 2015). The assumption that formal education is limited to the formality in building the human resources and just prioritizing the implementation only (Handitya, 2018), gives the new challenges for education in this current era. Therefore innovation in education will continue to be carried out with a background of several things, such as the development of science and technology, the growth of population, the increasing of public interest in obtaining better quality of education, the declining quality of education, and the existence of education relevance to the skills in the world of work [5. p. 118].

\section{Learning that Inspire, Enlighten, and Revive Islamic Values in the Disruption Era}

Industrial revolution 4.0, which has increasingly opened an extensive invasion in technology has impacted fundamental change or disruption of social life (Muslich, 2018). At least there are two views of either positivism or pessimism. For some who have positivist views, the technological advancements that are increasingly advanced will be able to facilitate human works, but on the contrary in the view of pessimism, the action involving humans will diminish and be replaced with machines (Butler \& Adam, 2018), (Ghufron, 2018) Therefore, as a mediator for future generations, schools as educational institutions must respond through a truly reconstructive education curriculum design.

The importance of curriculum in Islamic education, especially in this fast-paced era of disruption has directed to reforms it from various aspects. Dacholfany [2015] said that the formulation of the curriculum renewal included changes in the conceptions, contents, practices, and programs of Islamic education. For example, the rearrangement of the Islamic education concept which is truly based on the basic assumptions about humans, especially in the fitrah or the human potentiality by empowering them with the expectations, demands, and changes of society. Furthermore, designing Islamic education heading on the integrity between the sciences of naqliah and the sciences of 'aqliah, so there is no gap occurs between sciences called general science and religion. As Fazlur Rahman concluded that renewal in Islamic education is the ability of Islamic education in combining two elements of excellence in civilization in the world today (Igbal, 2015) or in other words the ability of an Islamic education curriculum which can integrate religious knowledge with general science and technology is certainly will be more directed at the progress of Islamic education at this time. Therefore, in order to achieve the desired goals of Islamic education, the curriculum which has a position as part of Islamic education programs such as vision, mission, material, strategy, management, funding, leadership, community and government support currently requires a new paradigm arrangement (Sanaky, 2008).

From the psychological side, the development or reconstruction of the curriculum should be based on the psychology of human development and the psychology of learning. In the psychology of human development which studies about person's behavior, it will be related to the essence, the stages, the elements, the tasks of development, and others. Similarly, the psychology of learning which studies about the behavior in the context of learning will be associated with the essences and theories of education, as 
well as various aspects of other individual practice in learning (Sukmadinata, 1997). In this case, the theory of the learning psychology has revealed that the highest achievement of the thought process of the taxonomy bloom which was revised in 2001 is creative (Sousa, 2012). Generally, it can be concluded that the end of the process, creative thinking is the main key to achieve success (Tyan, 2005). For this reason, in order to achieve these highest levels, the process of Islamic education in schools must be followed by various learning stimulations that inspire, enlighten and revive Islamic values.

It was followed by the era of disruption or better known as the industrial revolution era 4.0 which is currently happening and has an impact on changing the lives and systems of social work (Handitya, 2018), then the whole aspects of life including education must adjust. Therefore, the learning simulations are not enough just to the minimum. Connectivity between millennials and data which is connected everywhere (cyberspace), certainly has provided new challenges for Islamic education.

The millennial generation, which has been known technology devices (smartphones, internet, applications, tablets, gadgets), etc. (Muslich, 2018), currently has changed, both in their patterns and behavior, including in terms of learning. Submitting monotonous and boring material will be quickly rejected consciously or unconsciously by this generation. This resulted in the strengthening of Islamic values that would be difficult to convey. For this reason, the utilization of technology to make learning that is more enjoyable, inspiring and full of benefits, mainly Islamic values, is the result of the curriculum reconstruction that crucial to be applied.

Pulungan [29. p. 24] found that ethical and moral learning with digital learning materials and utilization of PowerPoint have been positively impacted student learning motivation. Similarly, Oemar H. Malik (Abadi, 2015) added that the use of media in the learning process could also increase new desires and stimulate the learning process, as well as positively influence students' psychology. Thus, by reviewing the usefulness, the process of Islamic Education in this era of disruption should properly change itself. Educative interaction between students, teachers and the environment will be more effective and efficient when bridged by the media or technology in it as well as the positivist view of the changes that occur at this time.

\section{CONCLUSION}

As the importance of Islamic education in maximizing human potential and advancing a nation, then as the curriculum is viewed essential position in the process of education. The central place of the curriculum not only as a document that must be completed at one school, but more than that includes all forms of educational activities. In the process of Islamic education, without a curriculum, it will be difficult to achieve its objectives as well as the learning process will not be carried out effectively and efficiently. The concepts, contents, practices and educational programs have been customized and designed in such a way by experts based on various aspects of either philosophy or psychology. This is none other than intended to achieve maximum results. However, undeniable that the changing times have affected a wide range of areas, including education. Similarly, the achievement of the objectives of Islamic 
education is also more or less influenced by these factors. Therefore, curriculum design is increasingly required to be able to reconstruct themselves in the face of various changes to achieve the desired goals.

Currently, the learning approach that uses digital technology-based devices is still very rarely applied in schools. For this reason, it would be better if the learning curricula are developed through various learning media because the millennial generation, which is known to be very fast in moving and quickly bored with a monotonous situation would be more easily aroused with exciting and fun media. Therefore, in future research, learning media are expected to emerge that can lead to the development of an educational process that further inspires, enlightens and revives Islamic values.

\section{REFERENCES}

Abadi, G. F. (2015). Inovasi Pembelajaran Pendidikan Agama Islam Berbasis E-Learning. Tasyri', 22(2), $127-138$.

Ahid, N. (2006). Konsep dan Teori Kurikulum dalam Dunia Pendidikan. Islamica, 1(1), 12-29.

Ainiyah, N. (2013). Pembentukan Karakter Melalui Pendidikan Agama Islam. Al-Ulum, 12(1), 25-38.

Anwar, B. (2016). Pendidikan islam melalui kemahiran berfikir membentuk moral dan akhlakul karimah pelajar islam. Al-Daulah, 5(2), 341-351.

Arjunes, A., \& Mojokerto, T. M. J. M. I. K. A. C. P. (2016). Kebijakan Pengembangan Pendidikan. Yogyakarta: Ladang Kata.

Asri, M. (2017). Dinamika Kurikulum di Indonesia. Modeling: Jurnal Program Studi PGMI, 4(2), 192202.

Azra, A. (2001). Pendidikan Akhlak dan Budi Pekerti 'Membangun Kembali Anak Bangsa'.' Mimbar Pendidikan, $1(\mathrm{XX})$.

Bahri, S. (2011). Pengembangan Kurikulum Dasar dan Tujuannya. Jurnal Ilmiah: Islam Futura, XI(1).

Butler, \& Adam. (2018). The Fourth Industrial Revolution and Education. South African Journal of Science, 114(5), 1-1. https://doi.org/10.17159/sajs.2018/a0271

Buzan, T. (2003). Use Both Sides of Your Brain. Yogyakarta: Ikon Teralitera.

Cooper, C. (2004). ' A struggle well worth having ': the uses of theatre-in-education ( TIE ) for learning. Support for Learning, 19(2), 81-88.

Dacholfany, M. I. (2015). Reformasi Pendidikan Islam dalam Menghadapi Era Globalisasi: Sebuah Tantangan dan Harapan. Akademika, 20(01), 173-194.

Effendi, M. (2013). Integrasi Pembelajaran Active Learning dan Internet-Based Learning dalam Meningkatkan Keaktifan dan Kreativitas Belajar. Nadwa: Jurnal Pendidikan Islam, 7(2).

El-Rahman, T. dan A. J. (2017). Tips Menjadi Guru Kreatif Inovatif. Banjarbaru: Penakita.

Fazlurrahman, M. (2018). Modernisasi Pendidikan Islam: Gagasan Alternatif Fazlur Rahman. TA'LIM: Jurnal Studi Pendidikan Islam, 1(1), 73-89.

Ghufron, M. A. (2018). Revolusi Industri 4.0: Tantangan, Peluang dan Solusi Bagi Dunia Pendidikan. In Seminar Nasional Dan Diskusi Panel Multidisiplin Hasil Penelitian Dan Pengabdian Kepada Masyarakat, 1(1), 332-337.

Handitya, B. (2018). Peran Pendidikan Dalam Membangun Moral Bangsa di Era Disrupsi. Seminar Nasional Jurusan Politik Dan Kewarganegaraan UNNES, 41-52.

Igbal, A. M. (2015). Pemikiran Pendidikan Islam: Gagasan-Gagasan Besar Para Ilmuan Muslim. Yogyakarta: Pustaka Pelajar.

Jalaluddin. (2007). Psikologi Agama. Jakarta: PT. RajaGrafindo Persada.

Khotimah. (2014). Pemikiran Fazlur Rahman Tentang Pendidikan Islam. Jurnal Ushuluddin, 22(2), 239253.

Langgulung, H. (1986). Manusia dan Pendidikan: Suatu Analisa Psikologi Pendidikan. Jakarta: Pustaka Al-Husna.

Ma'arif, M. A. (2017). Manajemen Pengembangan Kurikulum Pendidikan Agama Islam. At Ta'lim: Jurnal Pendidikan, 3(1), 89-117. 
Manab, A. (2015). Manajemen Perubahan Kurikulum: Mendesain Pembelajaran. Yogyakarta: Kalimedia.

Mulyasa, H. E. (2015). Guru Dalam Implementasi Kurikulum 2013. Bandung: PT. Remaja Rosdakarya.

Mumtahanah, N. (2011). Gagasan Hasan Langgulung tentang Pendidikan Islam. Al Hikmah, 1(1).

Murdiono, M. (2010). Strategi Internalisasi Nilai-Nilai Moral Religius dalam Proses Pembelajaran di Perguruan Tinggi. Cakrawala Pendidikan, XXIX(Edisii Khusus Dies Natalis UNY), 99-111.

Muslich, A. (2018). Nilai-nilai Filosofis Masyarakat Jawa dalam Konteks Pendidikan Karakter di Era Milenial. Al-Asasiyyah: Journal Basic of Education, 02(02), 65-78.

Nuryana, Z., Rahman, A., \& Setiawan, F. (2019). The Curriculum Model of Study Program-based Muhammadiyah Form of Cadre. Proceedings of the First International Conference on Progressive Civil Society (ICONPROCS 2019). https://doi.org/10.2991/iconprocs-19.2019.44

Oviyanti, F. (2013). Tantangan Pengembangan Pendidikan Keguruan di Era Global. Nadwa, 7(2).

Pulungan, S. (2017). Pemanfaatan ICT Dalam Pembelajaran PAI. QUERY: Jurnal Sistem Informasi, 01(01), 19-24.

Purwati, E. (2016). Optimalisasi Pendidikan Islam Melalui Pembelajaran Berbasis Cara Kerja Otak. Islamica, 11(1), 86-112.

Rose, C., \& Nichall, M. J. (2015). Revolusi Belajar: Accelerated Learning For the 21 st Century. Bandung: Nuansa Cendekia.

Rusydi, I. (2014). Pendidikan Berbasis Budaya Cirebon. Intizar, 20(2), 327-348. https://doi.org/10.1002/(SICI)1097-4571(199207)43:6<397::AID-ASI1>3.0.CO;2-M

Sanaky, H. A. H. (2008). Permasalahan dan Penataan Pendidikan Islam Menuju Pendidikan yang Bermutu. El-Tarbawi: Jurnal Pendidikan Islam, I(1), 83-97.

Sauri, S. (2010). Membangun karakter bangsa melalui pembinaan profesionalisme guru berbasis pendidikan nilai. Jurnal Pendidikan Karakter, 2(2), 1-16.

Soedijarto. (2004). Kurikulum, Sistem Evaluasi, dan Tenaga Pendidikan sebagai Unsur Strategis dalam Penyelenggaraan Sistem Pengajaran Nasional. Jurnal Pendidikan Penabur, 3(3), 89-107.

Sousa, D. A. (2012). Bagaimana Otak Belajar: Edisi Keempat. Jakarta: Tim Indeks.

Sukmadinata, N. S. (1997). Pengembangan Kurikum; Teori dan Praktek. Bandung: Remaja Rosdakarya.

Talbani, A. (2018). Pedagogy, Power, and Discourse: Transformation of Islamic Education. Comparative Education Review, 40(1), 66-82. https://doi.org/10.1086/447356

Tyan, B. (2005). Melatih Anak Berpikir seperti Jenius: Menemukan dan Mengembangkan Bakat yang Ada pada Setiap Anak. Jakarta: PT. Gramedia Pustaka Utama.

Umam, M. K. (2018). Reconstruction of Integrative Islamic Education in the Transformative Profetical Education Framework. Proceedings of Annual Conference for Muslim Scholars, 1(April), 511-520.

Wenger, W. (2003). Beyond Teaching and Learning: Cara Praktis Menerapkan Quantum Teaching and Learning (I). Bandung: Nuansa.

Wirianto, D. (2014). Perspektif Historis Transformasi Kurikulum di Indonesia. Islamic Studies Journal, 1(2).

Zalik Nuryana. (2017). Curriculum 2013 and The Future of Islamic Education in Indonesia. International Seminar On Islamic Education 2017. https://doi.org/10.31227/osf.io/e2d9x 